\title{
UTILIZATION OF CORN RESIDUES FOR WATER FILTRATION AT FISH TANKS
}

\section{A. M. A EL-Sheikha. ${ }^{1}$ M. A. Al- Rajhi ${ }^{2}$}

\section{ABSTRACT}

Filtration has been widely used in re-circulating aquaculture system to remove waste. However, the study of some agricultural residues (corn) usage as the filter medium has not yet been studied. Therefore, the aim of this study is to construct a filter made from inexpensive and readily available corn residues and to analyze its effectiveness in controlling suspended solids that directly impact health of fish through abrasion of gill tissues or indirectly through water quality deterioration. The performance evaluation procedure was carried out in an aquaculture system with production in glass tanks located indoor in laboratory at Faculty of Agriculture, Damietta University, Egypt. The evaluation included three concentrations of total suspended solids (450, 900 and $1350 \mathrm{mg} / \mathrm{l})$; four residues particle size distribution (3.35, 9.53, $12.7 \mathrm{~mm}$ and ascending order to mentioned sizes from bottom to top); and four thicknesses of filter layer $(9,21,33$ and $45 \mathrm{~cm})$. The effectiveness of this filter was measured by determining filter efficiency ( $\eta f), \%$ and filtration rate $(F R), \mathrm{ml} / \mathrm{min}$. It was observed that the maximum value of ( $\eta f), \%$ was achieved at $450 \mathrm{mg} / \mathrm{l}$ concentration of total suspended solids, ascending order to sizes from bottom to top and $45 \mathrm{~cm}$ thickness of filtration layer. The maximum value of filtration rate was achieved at $450 \mathrm{mg} / \mathrm{l}$ concentration of total suspended solids, $12.7 \mathrm{~mm}$ particle size distribution and $9 \mathrm{~cm}$ thickness of filter layer. Results indicated that this filter is efficient enough to remove suspended solids. Therefore, this milled corn residues filter can be used in aquaculture systems for Nile tilapia, Oreochromis niloticus culture system.

Keywords: Agricultural residues, corn, filter, re-circulating aquaculture system, total suspended solids, filtration rate.

\section{${ }^{1}$ Lecturer. Ag. Eng. Dept., Fac. of Ag. Damietta University. ${ }^{2}$ Researcher, Ag. Eng. Res. Institute, AnERI, ARC. El-Doki-Egypt.}




\section{INTRODUCTION}

$\mathrm{F}$ Tield crop residues are considered one of the critical problems, which face the Egyptian farmer especially after harvesting. In Egypt, about 30 million tons of agricultural residues are generated each year (Ministry of Agriculture, Egypt 2007). Egyptian farmers burn yearly about 5.87 million ton of corn stalks as a means for disposing it and to save time for preparing the land of the next crop (Helmy et al., 2003). The utilization of field crop residues instead of burning them became an important point of research because these residues are considered to be a heavy burden and a serious environmental problem at the national level.

Aquaculture is defined as the culture of finfish, shellfish, other aquatic animals, and aquatic plants in either freshwater or saltwater (Lawson, 1995). Fish is an excellent source of good-quality proteins, lipids and a wide variety of essential nutrients. Egypt production from lakes and other source of fresh water estimated about 387 thousand tons and imported 220 thousand tons annually. So that tended to encourage state aquaculture, producing about 668 thousand tons per year. (Central Agency for Public Mobilization and Statistics, 2011). In 2015, the production from aquaculture will be 74 million tons (FAO, 2012). Intensive fish culture under controlled conditions is one of the areas of aquaculture that is developing dynamically since it allows limiting production costs and permits controlling culture conditions fully (Remen et al. 2008). Therefore, aquaculture has been a topic of ongoing research in order to improve the production techniques and to optimize the use of water (Quazi, 2001). Nile tilapia, Oreochromis niloticus is the ninth most important aquaculture species group in terms of weight of production worldwide. Data from FAO on world tilapia production by capture fisheries and aquaculture from 1993 to 2003 are illustrated that, total production increased from 1.0 million metric tons $(\mathrm{mt})$ in 1993 to 2.3 million $\mathrm{mt}$ in 2003. Aquaculture production increased from about $550,000 \mathrm{mt}$ to slightly over 1.7 million $\mathrm{mt}$ during this time, while the production from capture fisheries changed little. Aquaculture production of tilapias worldwide has more than doubled since 1993. 
The main wastes from aquaculture operations are uneaten feed, undigested feed residues, excretion products, chemicals and therapeutics, as described by Ackefors and Enell (1994). To produce $1 \mathrm{~kg}$ live weight fish one needs $1-3 \mathrm{~kg}$ dry weight feed (assuming a food conversion ratio about 1-3) (Naylor et al., 2000). About 36\% of the feed is excreted as a form of organic waste (Brune et al., 2003). An intensive aquaculture system, which contains 3 ton tilapia, can be compared on a biomass basis to a human community with 50 inhabitants (Helfman et al., 1997). This intensive aquaculture system can also be compared on grounds of waste generation to a community of around 240 inhabitants (Flemish government, 2005). It can thus be concluded that live fish biomass generates approximately 5 times more waste than live human biomass. The reason is that the scope of digestion in fish is limited; a relatively large fraction of feed remains undigested and is excreted (Amirkolaie, 2005). It is recognized that the size of solids particles produced in an aquacultural system depends primarily on the type of food used and the size of the animal raised (Muir, 1982). It is estimated that 250-300g of solid waste (uneaten feed and faeces) is generated for every $1 \mathrm{~kg}$ of feed added (Losordo and Westers 1994). Solids can commonly carry 7-32\% of the total nitrogen and $30-84 \%$ of the total phosphorus in the wastewater (Cripps and Bergheim, 2000). The feed portion is not assimilated by the fish excreted as an organic waste (fecal solids) and the uneaten feed consume dissolved oxygen and generate total ammonia nitrogen (TAN) when broken down by bacteria within the system (Timmons and Ebeling, 2007).

Recirculation aquaculture systems (RAS) are systems in which water is (partially) reused after undergoing treatment (Rosenthal et al., 1986). Recirculating aquaculture system (RAS) technology for high-density fish culture is one such technology that is becoming very popular Throughout the world and has attracted considerable attention over the years due to its greatly reduced land and water requirements, a high degree of environmental control and high production rates (Verdegem et al., 2006), improved opportunities for waste management and nutrient recycling (Piedrahita, 2003) and for a better hygiene and disease management (Summerfelt et al., 2009; Tal et al., 2009), biological pollution control 
(Zohar et al., 2005), and reduction of visual impact of the farm. RAS technology relies considerably on biological filtration as the mechanism for removing critical pollutants (Guerdat et al, 2009). Water recirculation dramatically reduces the possibility of pathogen introduction (Davis 1990; Goldburg et al. 2001). Intensive water reuse systems allow freedom from site limitations, reduction of labor per unit production, improved environmental control, increased product quality and availability, and facilitate the control of stock and effluent management (Lee, 1993). The intensive development of the aquaculture industry has been accompanied by an increase in environmental impacts. The production process generates substantial amounts of polluted effluent, containing uneaten feed and feces (Read and Fernandes, 2003).

Because suspended solids can degrade water quality if not rapidly removed (Piedrahita et al., 1996), The effective management of solids in aquaculture is one of the major obstacles to the continued development of the aquaculture industry (Piedrahita and Giovannini, 1989) and is often considered the most critical process to manage in aquaculture systems (Summerfelt, 1996). Several studies have focused on strategies for removal of these solids from aquaculture effluents (Chen and Malone, 1991; Libey, 1993; Piedrahita et al., 1996; Summerfelt, 1996). The recommended maximum limit for TSS varies between $15 \mathrm{mg} / \mathrm{L}$ (Timmons and Ebeling, 2007), 80-100 mg/L (Wedemeyer, 1996), and 10-80 mg/L, depending on fish species (Timmons and Ebeling, 2007). These solids tend to reduce the clarity of water and also reduce a tremendous amount of oxygen. Filtration or clarification is the process of removing suspended solids from water. Suspended solids in a recirculating system are generally small particles of undigested food, bacteria, and algae. Suspended solids are defined as particulate matter within the water with a diameter greater than $1 \mu \mathrm{m}$ where the solids have organic and inorganic components (Chen et al., 1994). The suspended solids are very objectionable in water for many reasons. Mineral and organic suspended matters can lead to silting and by blanketing the river/sea bed causing destruction of plant and animal. Furthermore, gritty material may cause physical injuries to fish (Alabaster JS and Lloyd $R$, 1982). 
Table 1: The proposed water quality standards for aquaculture based on TSS values (Jabatan Perikanan, 1984).

\begin{tabular}{|c|c|}
\hline Type of water & TSS, mg/L \\
\hline Very clean & $0-25$ \\
\hline Clean & $25-80$ \\
\hline Slightly polluted & $80-200$ \\
\hline Moderately polluted & $200-400$ \\
\hline Grossly polluted & $>400$ \\
\hline
\end{tabular}

Recently, many commercial biofilter media and operating systems have been developed and utilized on commercial scales (Sandu et al., 2002). Sand, polypropylene bioblock Polystyrene microbeads, and Kaldnes beads are commonly used as biofilter media. These media have their own advantages and disadvantages. Sand has high specific surface area (SSA) because the sand particles are small. However, because of the specific gravity of sand (i.e., 2.65), it is much heavier than water (Summerfelt, 2006), and thus a sand filter needs a strong pump to fluidize it (Wheaton et al., 1994). This will be as a result of: a direct impact of the solids on the animals, e.g. through the partial smothering of gills; or indirectly, e.g. by offering a suitable habitat for the proliferation of pathogenic organisms (Liltved and Cripps, 1999), and the consumption of dissolved oxygen as the solids decay (Welch and Lindell, 1992). Alabaster and LIoyd (1982) concluded that there were at least five ways in which an excessive concentration of fine suspended solids in a lake or river might be harmful to afishery - including killing fish, reducing their growth rate, increasing their susceptibility to disease, etc. further research has provided more evidence which suggests suspended solids can directly damage fish gills, even at low concentration $44 \mathrm{mg} / \mathrm{l}$ (Magor, 1988). A high concentration of suspended solids has a negative influence on nitrification, water quality (Eding et al., 2006) and fish growth (Davidson et al., 2009). Rapid and effective solids removal can positively affect the health of salmonid species in water recirculating systems (Bullock et al., 1997). These smaller suspended solids can cause gill irritation, which can lead to reduced immune system efficiency, and ultimately disease outbreak (Wickens, 1980). In conventional aquaculture wastewater treatment systems, solids are removed by gravitational and/or mechanical methods. Settlement is used to remove the denser solids, 
while filtration (commonly screen filtration, expandable granular biofilters (EGBs), and foam fractionation) is used for removing suspended and fine solids (Cripps and Bergheim, 2000; and Piedrahita, 2003). For fine solids removal, foam fractionation - a process also referred to as air stripping or protein skimming - is often employed (Hussenot, 2003).Bead filters remove solids from water by different mechanisms. Physical straining is probably the most dominant mechanism removing larger particles ( $>50$ microns). Finer particles $(<20$ microns) are removed at a lower rate by a process called bio-absorption. The particles are captured by bacterial biofilm on the surface of the bead. The more passes the more solids captured (Selective Koi Sales, 2011 ; Russel Water Gardens, 2011). Bead filters or expandable granular biofilters (EGBs) can function as both mechanical and biological filters (Chen et al., 1993a,b) and because of this they have been used for recycle systems. Chen et al. $(\mathbf{1 9 9 3 a}, \boldsymbol{b})$ claimed that the filter offered both high hydraulic loading rates and removal of particles smaller than 100 mm. Chen et al. (1993a,b, 1994), and Malone et al. (1998) described the functioning of bead filters. Buoyant, inert, 3- to 5-mm diameter polyethylene beads retained within the filter housing are fluidised as the wastewater is up-flowed through the bead bed. Suspended particles are either strained out or deposited on the bead surface. Flow to the filter is then stopped and the beads are aggressively backwashed. Data presented by Bergheim et al. (1998) showed that treatment efficiency, in terms of the separation of particles from the effluent, increased with increased solids concentration. This indicates both that aquaculture wastes solids are difficult to treat, and that by increasing the concentration prior to treatment, an increase in treatment efficiency, or clarification rate, would be expected. Several authors have reviewed particle separators, including Landau (1992); Lawson (1995); Chen et al. (1994); and Cripps and Kelly (1996). Re-circulating aquaculture systems are slowly starting to develop in Egypt. Few Egyptian aquaculture breeders tend to operate mechanical filtration in separate filter tanks. As solids separation technology can be conveniently divided into mechanical and gravitational methods. The needs to develop indigenous location specific RAS components have led to research into various local materials that can be used as different components of RAS. 
Corn stems are in general a low quality feed for Cattle, so this study investigated the performance of corn stems, a locally available agricultural waste material in controlling suspended solids that directly impact health of fish through abrasion of gill tissues or indirectly through water quality deterioration.

Therefore, the objectives of the present study were as follows:

a) to increase farm productivity and profitability without any net increase in water consumption.

b) to control suspended solids that directly impact health of fish through abrasion of gill tissues or indirectly through water quality deterioration.

c) to study and recommend the best combination of operating parameters for the corn residues filter that maximize the filtration efficiency $\left(\eta_{\mathrm{f}}\right)$, $\%$ and filtration rate $(\mathrm{FR}), \mathrm{mL} / \mathrm{h}$.

\section{MATERIALS AND METHODS}

\section{1- Materials}

In this study we reared the most important aquaculture species group (Nile tilapia, Oreochromis niloticus with average weight $0.166 \mathrm{~kg}$ ) in glass tanks located indoor (in laboratory at Faculty of Agriculture, Damietta university, Egypt) to prevent the entry of rainwater and sunlight. A filter from corn residues were used for filtration suspended solids from water.

\section{$\underline{\text { 1-1 Filter Description }}$}

Figure (1a) illustrate the parts of studied corn residues filter. It was made from plastic with a cylinder shape $(50 \mathrm{~cm}$ height $\mathrm{x} 10 \mathrm{~cm}$ dia). The filter was gravity fed. Wastewater was run through the columns of corn residues and the filtrate was return to the glass tank. For safety purposes the thickness of the tank should be sufficient enough to withstand the hydraulic pressure generated by the water flowing from the culture tanks. Pieces of corn residues with same diameter were used as a filter. Once the filter was fabricated, its function and operation were tested to ensure its performance ability. The filter was connected to a $0.125 \mathrm{~m}^{3}$ glass tank with 11 Nile tilapia, Oreochromis niloticus [average weight $0.166 \mathrm{~kg}$ ] using PVC pipes and a small submersible pump, that was used to pump water from the glass tank into the filter. The filtered water will flow out 
from the filter by hydrostatic pressure and return to the glass tank Figure (1b), forming a re-circulating aquaculture system. Throughout the study, submersible heaters were also used to maintain the water temperature at $23 \pm 1^{\circ} \mathrm{C}$. The $\mathrm{pH}$ was controlled using soda addition to keep values above 7.1 (Fivelstad et al., 1995, 1998; Sammouth et al., 2009). The systems were equipped with an aeration system to maintain the dissolved oxygen level up to $70 \%$ of saturation (Buentello et al., 2000) in the culture tanks.

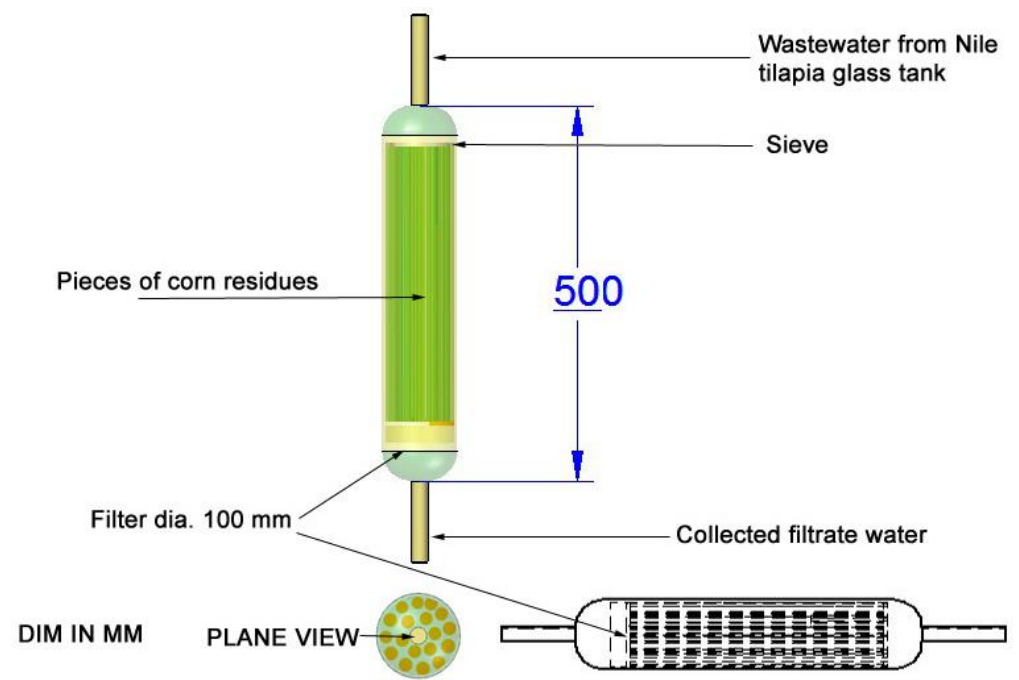

Fig. 1a: Corn stems filter.

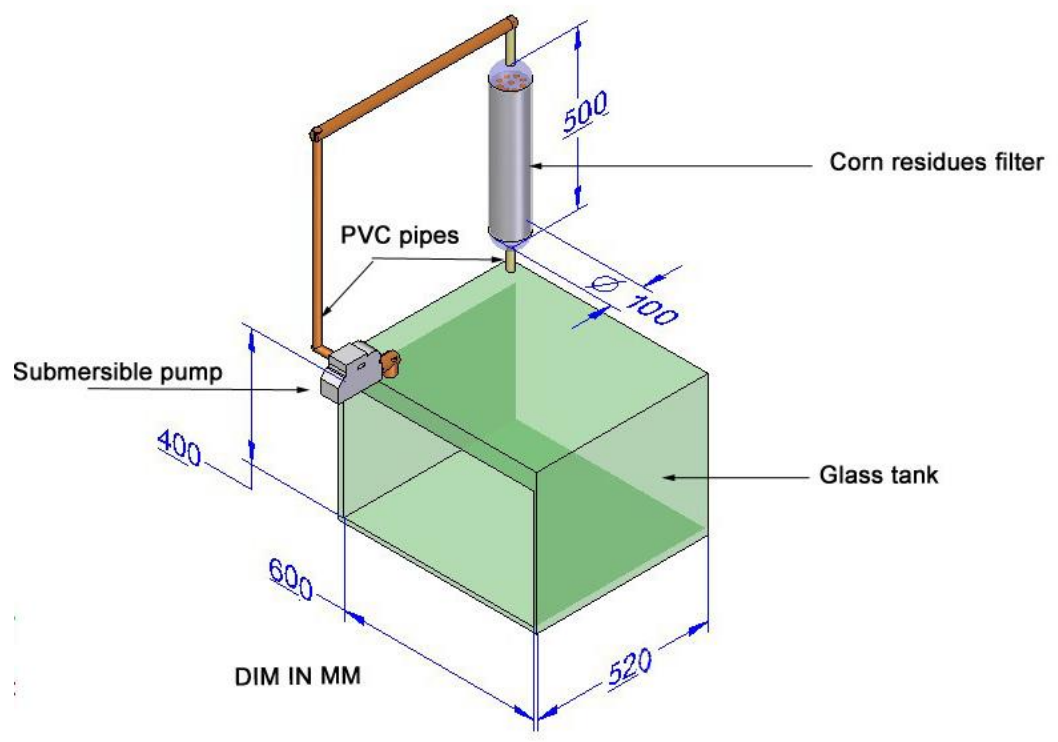

Fig. 1 b Designed filtration system 
After operating for some time, the sludge from the filtration tends to accumulate on the top cross section of corn residues. This condition decreased the flow rate at the exit point of the filter. In order to overcome this problem, Filters in the treatments were cleaned by back washing with tap water to remove trapped suspended solids once every each treatment.

\section{1-2 Instrumentation}

1-Electric oven: - An air forced electric heater was used for drying samples until a constant weight.

2-Electrical balance: - Digital electric balance of 200 grams was used to determine the mass with an accuracy of $0.0001 \mathrm{~g}$.

3- Glass bottles: - Glass bottles were used to collect samples.

4- Stop watch: for measuring the net time spent during operation.

\section{1-3 Studied factors}

\section{A-Variable factors}

1- Concentration of total suspended solids, mg/l: - Three levels of TSS, $\mathrm{mg} / \mathrm{L}$ were used. They were 450, 900 and $1350 \mathrm{mg} / \mathrm{l}$ named $\mathrm{C}_{1}, \mathrm{C}_{2}$ and $\mathrm{C}_{3}$, respectively.

2- Residues particle size distribution, mm: - Four cases of Particle size distribution were used. They were $3.35,9.53,12.7 \mathrm{~mm}$ and ascending order to sizes from bottom to top named $\mathrm{P}_{1}, \mathrm{P}_{2}, \mathrm{P}_{3}$ and $\mathrm{P}_{4}$, respectively.

3-Thicknesses of filter layer, cm: - Four levels of thicknesses were used. They were 9, 21, 33 and $45 \mathrm{~cm}$ named $\mathrm{T}_{1}, \mathrm{~T}_{2}, \mathrm{~T}_{3}$ and $\mathrm{T}_{4}$, respectively.

\section{B- Relatively fixed factors}

1- Corn stalks variety: One-cross 10.

2- Corn Stem diameter: $31 \mathrm{~mm}$.

3- Corn Stem moisture content dry base: $9 \%$.

\section{2-Methods}

2-1 Residues particle size distribution, mm: was assessed by taking a sample of $10 \mathrm{~kg}$ from milling corn residues into laboratory and separating into three categories $(3.35,9.53$ and $12.7 \mathrm{~mm}$ ) by using three standard sieves (ASAE 2001). The total weight of samples and the mass of each product categories were weighed using a precise digital scale with an accuracy of $0.01 \mathrm{~g}$. 


\section{2-2 Moisture content; dry basis (M.C.db \%):}

The moisture content of plant stems was measured by taking random samples from stems and dried in air forced electric heater at $105^{\circ} \mathrm{C}$ at atmospheric pressure for ten hours. At the end of this time the constant mass showed that all moisture was driven off. The moisture content was calculated according to the following equation:

$$
M c_{d . b .}=\frac{M_{w e t}-M_{d r y}}{M_{d r y}} x 100 \rightarrow(1)
$$

Where:

$\mathrm{Mcdb}=$ Moisture content, dry basis $\%$.

$\mathrm{M}_{\text {wet }}=$ Mass of wet samples, $\mathrm{g}$. and

Mdry $=$ Mass of dry samples, $\mathrm{g}$.

\section{2-2 Performance analysis}

The experimental procedure that was carried out on the agricultural residue (corn stems) filter was filtration efficiency $\left(\eta_{\mathrm{f}}\right), \%$ and filtration rate $(\mathrm{FR})$, $\mathrm{mL} / \mathrm{s}$.

The filter operation was observed for seven days. Within this period, tests were done in order to test its performance efficiency. The tests were Total Suspended Solids [TSS], mg/L analysis and filtration rate (FR), $\mathrm{mL} / \mathrm{s}$. Samples were taken during the operation of the filter and were collected from outlet pipe for seven days in a row at 10 a.m. Fish were hand fed twice a day, in the morning at 9 am and in the afternoon at 3 $\mathrm{pm}$. The calculation of feed dosage is based on $3 \%$ of fish weight. The commercial sinking dry pellets manufactured by Amria for Fish Feed Meal Company was used. The feed ingredients composition percentage is shown in Table 1. After a 2-week conditioning period, all fish were fasted for one day and weighed, and the experiment was started. The mean body weight of the fish was $0.166 \mathrm{~kg}$. Fish were redistributed into the three filter systems. Each system was stocked with 11 fish. During the experimental period, the water in the aquaculture system was restored with freshly supplied water. 
Table 2: The composition percentages of fish diets

\begin{tabular}{|l|l|c|}
\hline S/N & FEED INGREDIENTS & $(\mathbf{\%})$ \\
\hline 1 & Wheat bran & 7.5 \\
2 & Fat/Oil & 5 \\
3 & Soybean meal & 27.5 \\
4 & Yellow maize & 47.5 \\
5 & Fish silage & 12 \\
6 & Premix & 0.3 \\
7 & DL.methionine & 0.2 \\
\hline
\end{tabular}

To determine the filter efficiency $\left(\eta_{\mathrm{f}}\right), \%$ on trapping suspended solids inside the system. Well mixed samples each one was about one liter were filtered through a filtration paper before and after filtration with corn stems filter and the residue retained on the filtration paper is dried to a constant weight from $103^{\circ} \mathrm{C}$ to $105^{\circ} \mathrm{C}$ in a drying oven. The mean value of three readings were taken to determine the total suspended solids [TSS], mg/l The variance in weight represents the filter efficiency on trapping suspended solids inside the system according to the following relation:-

$$
\eta_{f}=\frac{T S S_{1}-T S S_{2}}{T S S_{1}} \times 100 \rightarrow(2)
$$

Where:

$\mathrm{TSS}_{1}=$ the average weight of residue retained on the filtration paper before filtration, $\mathrm{mg}$.

$\mathrm{TSS}_{2}=$ of residue retained on the filtration paper after filtration, mg. The filtration rate $\left(\mathrm{F}_{\mathrm{R}}\right), \mathrm{ml} / \mathrm{min}$ was determined with the help of a digital stopwatch of 0.1 -sec. accuracy and a graduated flask. Filtration rate was calculated as follows:-

$$
F_{R}=\frac{S_{v}}{t}, \mathrm{ml} / \mathrm{min}
$$

Where:

$$
\begin{aligned}
& \mathrm{Sv}=\text { Sample volume, } \mathrm{ml} \\
& \mathrm{t}=\text { time of test duration (min.). }
\end{aligned}
$$




\section{2-4 Statistical analysis:-}

All obtained data was presented in figures and was analyzed statistically by using a computer program (Minitab Release 15) for estimating the probability at levels 1 and 5\%. The graphs were drawn using the Microsoft excel window 2013.

\section{RESULTS AND DISCUSSION}

Data illustrated in figures (2 to 4 ) show the comparative magnitude of mean percentage values of filter efficiency $(\eta f), \%$ and filtration rate (FR), $\mathrm{ml} / \mathrm{min}$.

The relationships between total suspended solids concentration, $\mathrm{mg} / \mathrm{l}$. and thicknesses of filtration media, $\mathrm{cm}$ on percentage values of filter efficiency $(\eta \mathrm{f}), \%$ and filtration rate $(\mathrm{FR}), \mathrm{ml} / \mathrm{min}$. can be represented by the following equations, respectively:

$$
\begin{array}{llll}
(\eta \mathrm{f}), \% \quad=94.8-0.01230 \mathrm{C}+0.225 \mathrm{~T}, & \mathrm{R}^{2}=71.9 \%, & \mathrm{P}<0.01 \\
(\mathrm{FR}), \mathrm{ml} / \mathrm{min} .=31.4-0.00944 \mathrm{C}-0.178 \mathrm{~T}, & \mathrm{R}^{2}=72.9 \%, & \mathrm{P}<0.01
\end{array}
$$

Effect of total suspended solids concentration, $\mathrm{mg} / \mathrm{l}$. on measurements:-

The filter efficiency $(\eta f, \%)$ and filtration rate $(\mathrm{FR}, \mathrm{ml} / \mathrm{min})$ were calculated according to equation 2 and 3 respectively. Figure 2 showed the effect of total suspended solids concentration, $\mathrm{mg} / \mathrm{l}$. on ( $\eta \mathrm{f}, \%)$ and (FR, $\mathrm{ml} / \mathrm{min}$ ). Results show that the mean ( $\eta \mathrm{f}, \%$ ) increases from $83.83 \%$ at total suspended solids concentration $1350 \mathrm{mg} / \mathrm{l}$. to $94.87 \%$ at total suspended solids concentration $450 \mathrm{mg} / \mathrm{l}$.. It is increased by $11.64 \%$ than the other treatment due to the high chance of suspended solids to pace through filtration media at higher concentrations. The lost mean (FR, $\mathrm{ml} / \mathrm{min}$ ) was $14 \mathrm{ml} / \mathrm{min}$ at total suspended solids concentration 1350 $\mathrm{mg} / \mathrm{l}$. because at the high amounts of suspended solids, it trapped (accumulated) and closed the top of filtration media. It was noticed that ( $\eta \mathrm{f}, \%)$ and (FR, $\mathrm{ml} / \mathrm{min}$ ) increased; with concentration of suspended solids, mg/l., according to the following descending order [450 mg/l. > $900 \mathrm{mg} / \mathrm{l}$. >1350 mg/l.]. The relationship between total_suspended solids concentration and each of filter efficiency $(\eta f), \%$ and filtration rate (FR), $\mathrm{ml} / \mathrm{min}$. can be represented by the following equations:
( $\mathrm{\eta f}), \%$
$=101-0.0123 \mathrm{C}$,
$\mathrm{P}<0.01$
(FR), ml/min. $=26.6-0.00944 \mathrm{C}$
$\mathrm{P}<0.01$ 

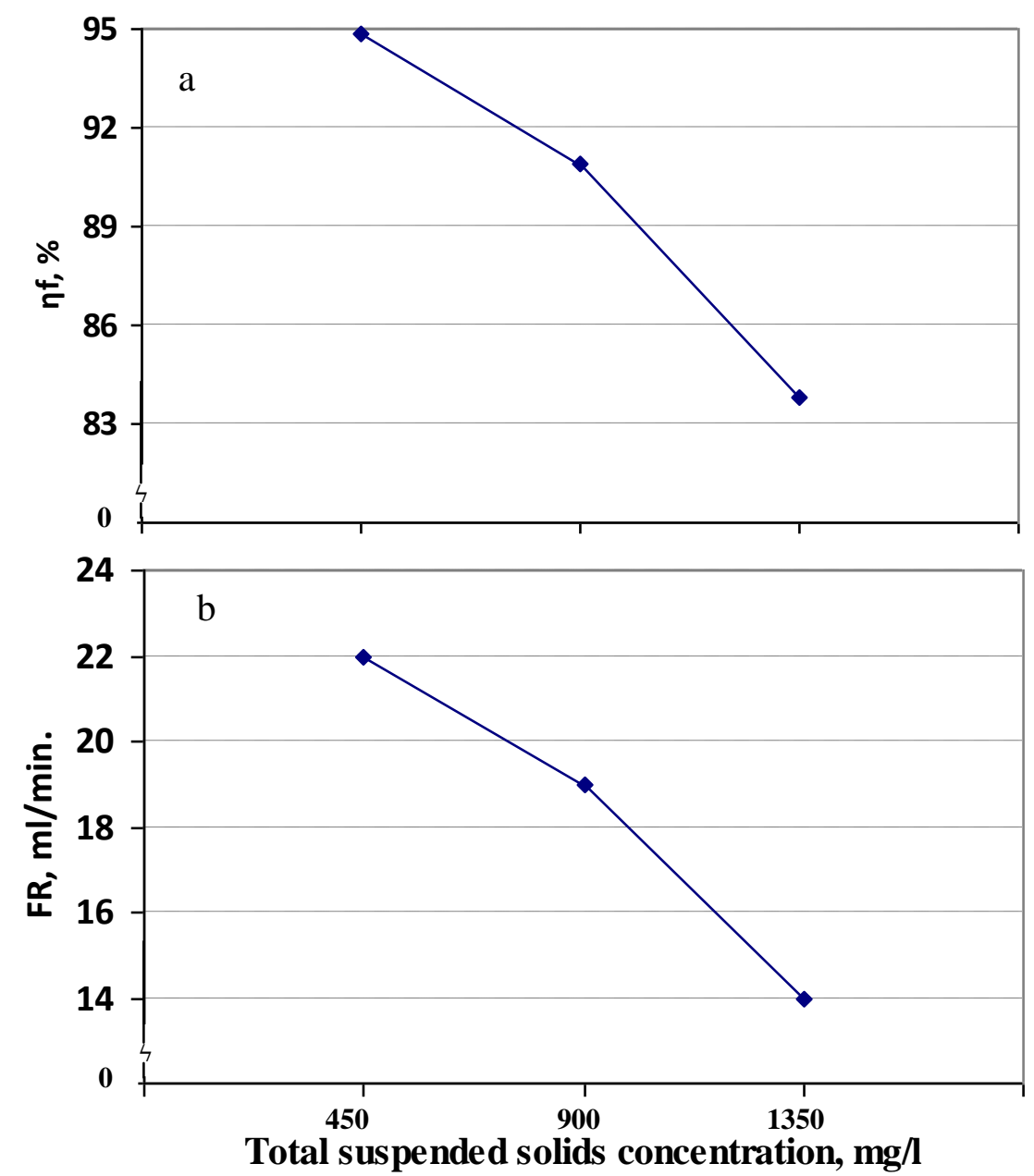

Fig. (2) Effect of total suspended solids concentration, $\mathrm{mg} / \mathrm{l}$ on ( $\eta \mathrm{f}), \%$ (a) and (FR), $\mathrm{ml} / \mathrm{min}$ (b).

Effect of residues particle size distribution,mm on measurements:-

The mean ( $\eta f$ value, figure 3) was $92.88 \%$ at ascending order to sizes from bottom to top. It is increased by $7.35 \%$ than the other treatment due to the gradation of wastewater filtration through filtration media. The mean (FR, $\mathrm{ml} / \mathrm{min}$ ) increases from $14 \mathrm{ml} / \mathrm{min}$ at residues particle size $3.35 \mathrm{~mm}$ to $21 \mathrm{ml} / \mathrm{min}$ at residues particle size $12.7 \mathrm{~mm}$. It is increased by $33.33 \%$ than the other treatment, because the suspended material clogs the small particle size of filtration media and prolongs filtration. It was noticed that ( $\eta \mathrm{f}, \%)$ increased; with particle size distribution, according to the following descending order $[12.7 \mathrm{~mm}<9.53 \mathrm{~mm}<3.35$ 
$\mathrm{mm}<$ ascending order to sizes from bottom to top] but the (FR, $\mathrm{ml} / \mathrm{min}$ ) increased with filtration areas, according to the following descending order [3.35 $\mathrm{mm}<$ ascending order to sizes from bottom to top $<9.53 \mathrm{~mm}$ $<12.7 \mathrm{~mm}]$.
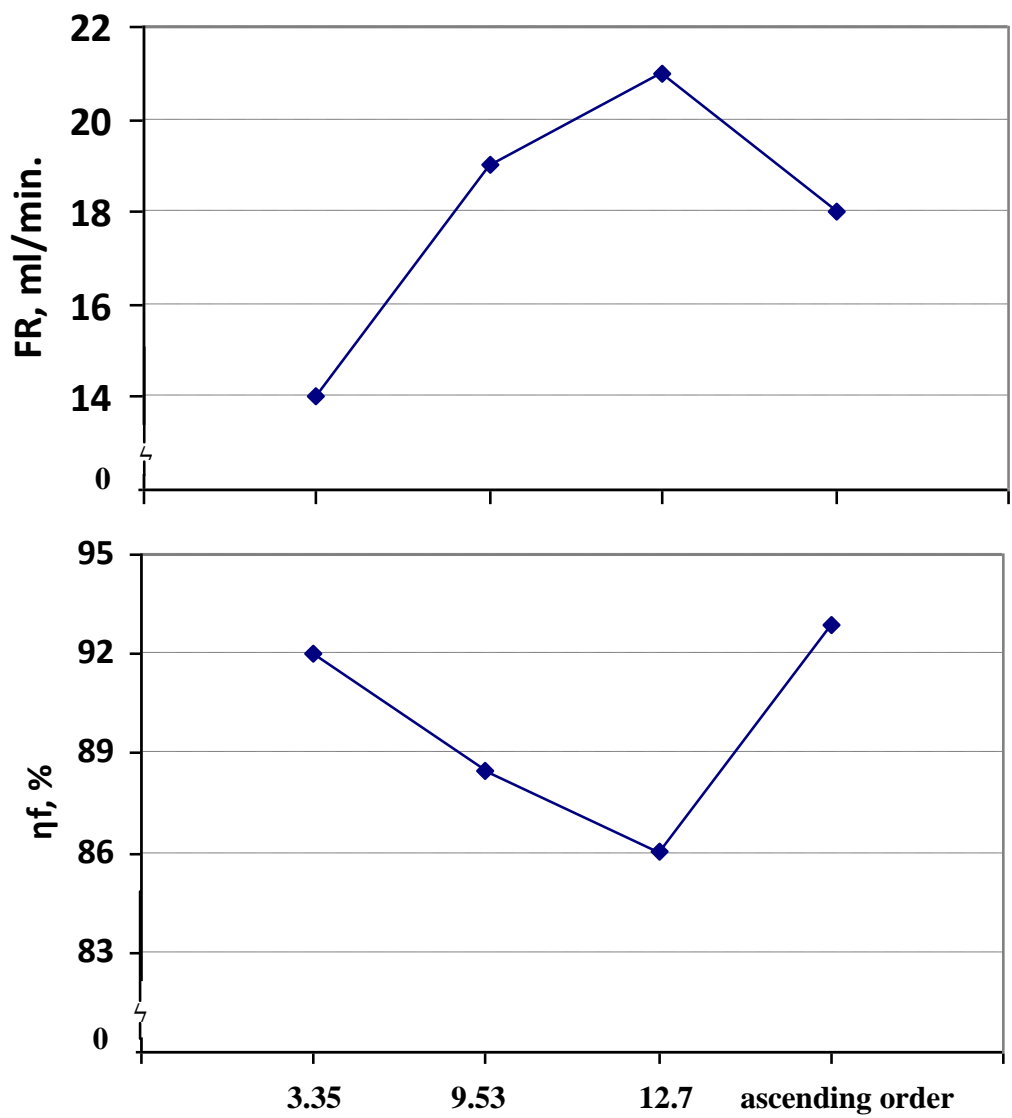

Particle size distribution

Fig. (3) Effect of residues, $\mathrm{mm}$ on ( $\eta \mathrm{f}), \%$ and $(\mathrm{FR}), \mathrm{ml} / \mathrm{min}$.

\section{Effect of filter layer thicknesses, cm on measurements:-}

When increasing the thicknesses from 9 to $45 \mathrm{~cm}$, the mean $\mathrm{\eta f}(\%)$ increased from 85.43 to $93.71 \%$.It is increased by $8.84 \%$ than the other treatment due to the long filtration column (figure 4), so it is necessary to increase thickness. The highest mean FR ( $\mathrm{ml} / \mathrm{min}$ ) was $22 \mathrm{ml} / \mathrm{min}$ at thickness of $9 \mathrm{~cm}$, due to the short filtration layer. It was noticed that 
$\eta \mathrm{f}, \%$ increased with thickness in descending order $(9 \mathrm{~cm}<21 \mathrm{~cm}<33$ $\mathrm{cm}<45 \mathrm{~cm})$. However, the $\mathrm{FR}, \mathrm{ml} / \mathrm{min}$ increased with thickness, according to the following descending order $(9 \mathrm{~cm}>21 \mathrm{~cm}>33 \mathrm{~cm}>45$ $\mathrm{cm})$. The relationship between filter layer thicknesses and each of filter efficiency ( $\eta \mathrm{f}), \%$ and filtration rate $(\mathrm{FR}), \mathrm{ml} / \mathrm{min}$. can be represented by the following equations:

$$
\begin{aligned}
& (\eta \mathrm{f}), \% \quad=83.8+0.225 \mathrm{~T}, \quad \mathrm{P}<0.01 \\
& (\mathrm{FR}), \mathrm{ml} / \mathrm{min} .=22.9-0.178 \mathrm{~T}, \quad \mathrm{P}<0.01
\end{aligned}
$$

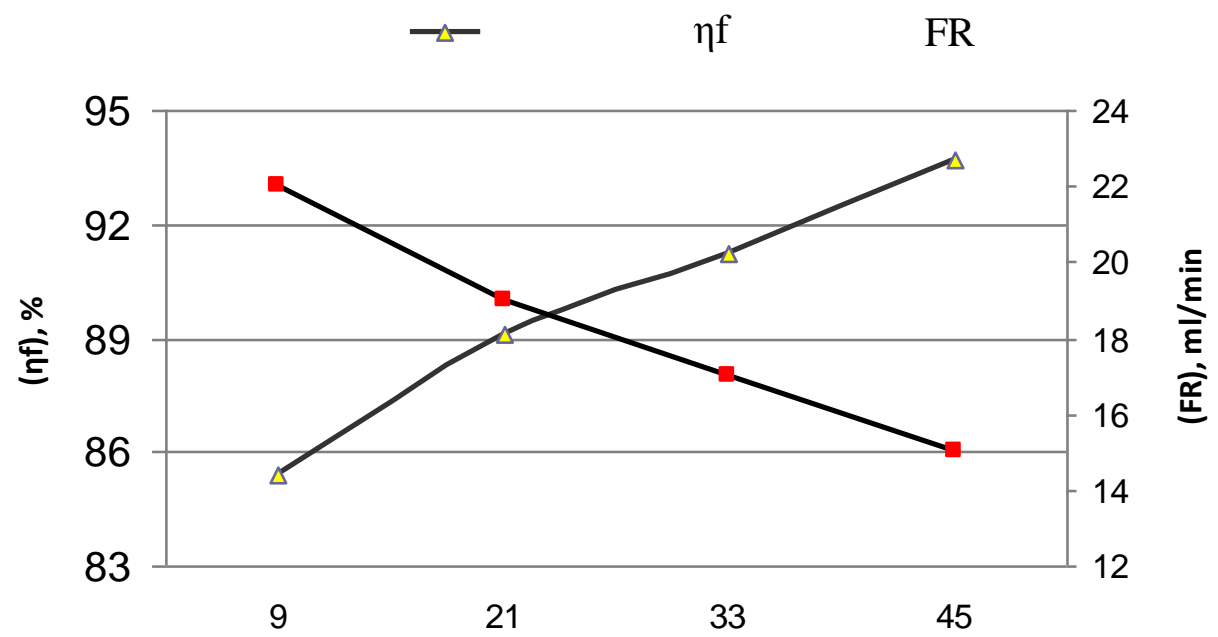

Thicknesses of infltration layer, $\mathrm{cm}$

Fig. (4) Effect of filtration layer thicknesses, cm on ( $\eta$ f), $\%$ and (FR), $\mathrm{ml} / \mathrm{min}$.

\section{CONCLUSIONS AND RECOMMENDATIONS}

Findings in the study established that corn residues are a good filter media. It was able to produce change in the selected water quality parameters that are within the limit for discharge into the environment and also safe for reuse in fish culture. It can be establish that corn residues filter media is a better material. It is also available at a cheaper price. Further research on the performance of the media is therefore recommended under continuous loading conditions as would be expected in a commercial aquaculture water reuse systems. Filters in the treatments were cleaned by back washing with tap water to remove trapped suspended solids once every 7 days. Some milled crop residues like rice straw and cotton stalks can be used as filter media. The system tested in this 
study may be able to reduce ammonia concentration; ammonia removal by filtration may be investigated in the future. A configuration may be designed to facilitate oxygen transfer if ammonia removal is desired. Metals and micronutrients primarily from feeds may be adsorbed on the organic surfaces and, thus, should be investigated in the future.

It was observed that the maximum value of $\left(\eta_{\mathrm{f}}\right), \%$ was achieved at $450 \mathrm{mg} / \mathrm{l}$ concentration of total suspended solids, ascending order to sizes from bottom to top and $45 \mathrm{~cm}$ thickness of filtration layer. These values fall under the very clean designation based on Water Quality Standards for Aquaculture (Jabatan Perikanan, 1984). Thus, the filter was proven to be efficient enough to remove suspended solids inside the glass tanks and transform the water condition from 'grossly polluted' to 'very clean'. Therefore, the filter functioned well and fulfilled its desired intention. The maximum value of filtration rate was achieved at 450 $\mathrm{mg} / \mathrm{l}$ concentration of total suspended solids, $12.7 \mathrm{~mm}$ particle size distribution and $9 \mathrm{~cm}$ thickness of filtration layer.

\section{REFERENCES}

Ackefors, H., Enell, M., 1994. The release of nutrients and organic matter from aquaculture systems in Nordic countries. J. Appl. Ichthyol. 10, 225-241.

Agricultural Statistics ,2007. Economic Affairs Sector. Ministry of Agr. and Land Rec. Cairo, Egypt.

ASAE ,2001. Methods of determining and expressing fineness of feed materials by sieving. American Society of Agricultural Engineering standards, 45th Ed. S 319.3, St. Joseph, Mich.

Alabaster JS and Lloyd R., 1982. Water quality criteria for freshwater fish. 2nd Edition, Food and Agriculture Organization of the United Nations, Butterworth's, London.

Amirkolaie, A.K., 2005. Dietary carbohydrate and faecal waste in the Nile tilapia (Oreochromis niloticus L.). $\mathrm{PhD}$ dissertation. University Wageningen, Wageningen, The Netherlands.

Bergheim, A., Cripps, S.J., Liltved, H., 1998. A system for the treatment of sludge from land-based fish-farms. Aquat. Liv. Res. 11, 279-287.

Brune,D.E., Schwartz, G., Eversole,A.G., Collier, J.A., Schwedler, T.E., 2003. Intensification of pond aquaculture and high rate photosynthetic systems. Aquac. Eng. 28, 65-86. 
Buentello JA, Gatlin III DM, Neill WH., 2000. Effects of water temperature and dissolve oxygen on daily feed consumption, feed utilization and growth of channel catfish (Ictalurus punctatus). Aquaculture, 182: 339352.

Bullock, G.L., Summerfelt, S.T., Noble, A., Weber, A.W., Durant, M.D., Hankins, J.A., 1997. Ozonation of a recirculating rainbow trout culture system: I. Effects on bacterial gill disease and heterotrophic bacteria. Aquaculture 158, 43-55.

Central Agency for Public Mobilization and Statistcs. 2011. MOAL,Egypt.

Chen, S., Coffin, D.E., Malone, R.F., 1993a. Production, characteristics, and modeling of aquacultural sludge from a recirculating aquacultural system using a granular media biofilter. In: Wang, J. (Ed.), Techniques for Modern Aquaculture. Proceedings of an Aquacultural Engineering Conference, 21-23 June 1993, Spokane, WA. American Society of Agricultural Engineers, St Joseph, MI, pp. 16-25.

Chen, S., Stechey, D., Malone, R.F., 1994. Suspended solids control in recirculating aquaculture systems. In: Timmons, M.B. and Losordo, T.M. (Eds.) Aquaculture Water Reuse Systems: Engineering Design and Management, 61-100. Elsevier, Oxford.

Chen, S. and R.F. Malone., 1991. Suspended solids control in recirculating aquacultural systems. Pp. 170-186. in Engineering aspects of intensive aquaculture. Northeast Regional Agricultural Engineering Service, Ithaca, New York.

Chen, S., Timmons, M.B., Aneshansley, D.J., Bisogni, J.J., 1993 b. Suspended solids characteristics from recirculating aquacultural systems and design implications. Aquaculture 112, 143-155.

Cripps S.J. and Bergheim A., 2000. Solids management and removal for intensive land-based aquaculture production systems. Aquacultural Engineering 22 (2000) 33-56.

Cripps, S.J., Kelly, L.A., 1996. Reductions in wastes from aquaculture. In: Baird, D.J., Beveridge, M.C.M., Kelly, L.A., Muir, J.F. (Eds.), Aquaculture and Water Resource Management. Blackwell, Oxford, pp. 166-201. 
Davidson, J., Good, C., Welsh, C., Brazil, B., Summerfelt, S., 2009. Heavy metal and waste metabolite accumulation and their potential effect on rainbow trout performance in a replicated water reuse system operated at low or high system flushing rates Aquacult. Eng. 41, 136-145.

Davis, J. T., 1990. Red Drum Brood Stock and Hatchery Production. SRAC Publication No.323, p. 4.

Eding, E.H., Kamstra, A., Verreth, J.A.J., Huisman, E.A., Klapwijk, A., 2006. Design and operation of nitrifying trickling filters in recirculating aquaculture: A review. Aquacult. Eng. 34, 234-260.

FAO. , 2012. The State of World Fisheries and Aquaculture; Food and Agriculture Organization of the United Nations: Rome, Italy, 2012. http://www.fao.org/ docrep/016 /i2727e/i2727e00.htm.

Flemish government, 2005. Afvalwaterproblematiek op melkveebedrijven.Flemish Government, Department Agriculture and Fisheries, Department Sustainable Agricultural Development, Belgium. $61 \mathrm{pp}$.

Goldburg, R. J., Elliott, M. S. \& Naylor, M. A., 2001. Marine Aquaculture in the United States: Environmental Impacts and Policy Options. Pew Oceans Commission, Arlington, VA, p. 44.

Guerdat T. C., T. M. Losordo, J. J. Classen, J. A. Osborne and D. P. DeLong, 2009. An Evaluation of Commercially Available Biological Filters for Recirculating Aquacul- ture Systems. Aquacultural engineering, Vol. 42, No. 1, 2010, pp. 38-49. doi:10.1016/j.aquaeng.2009.10.002.

Helfman, G.S., Collette, B.B., Facey, D.E., 1997. The Diversity of Fishes. Blackwell publishing, Malden, USA. 1006 pp.

Helmy, M.A; A.A. Abd EL-Rhman; M.T. Ebaid and M.A. Hassan (2003). Expectant production of biogas and fertilizer from different residues fermentation using biogas unit. Misr J.Ag.Eng., 20(4): 949- 964.

Hussenot, J.M.E., 2003. Emerging effluent management strategies in marine fish-culture farms located in European coastal wetlands. Aquaculture 226, 113-128. 
Jabatan Perikanan, 1984. Water quality for aquaculture in Malaysia. In: Risalah Perikanan Bil.20,Kementerian Pertanian Malaysia, Kuala Lumpur.

Landau, M., 1992. Introduction to Aquaculture. Wiley, New York, p. 440.

Lawson, T.B., 1995. Fundamentals of Aquacultural Engineering. Chapman and Hall, New York. 355 pgs

Lee, P.G., 1993. Computer automation for recirculating systems. In: Wang, J.K. (Ed.), Proceedings of an Aquacultural Engineering Conference, 2123 June 1993. American Society of Agricultural Engineers, St. Joseph, MI, pp. 61-70.

Libey, G.S., 1993. Evaluation of a drum filter for removal of solids. Pp. 519532 in J.K. Wang, editor. Techniques for modern aquaculture. American Society of Agricultural Engineers, St. Joseph, Michigan.

Liltved, H., Cripps, S.J., 1999. Removal of particle associated bacteria by prefiltration and ultraviolet irradiation. Aquacult. Res. 30, 445-450.

Losordo, T.M., Westers, H., 1994. System carrying capacity and flow estimation. In: Timmons, M.B., Losordo, T.M. (Eds.), Aquaculture Water Reuse Systems: Engineering Design and Management. Elsevier, Amsterdam, pp. 9-60.

Magor, B.G. 1988. Gill histopathology of juvenile Oncorhynchus kisutch exposed to suspended wood debris. Can. J. Zool. 66: 2164-2169.

Malone, R.F., Beecher, L.E., DeLosReyes, A.A., 1998. Sizing and management of floating bead bioclarifiers. In: Libey, G.S., Timmons, M.B. (Eds.), Proceedings of the Second International Conference on Recirculating Aquaculture, 16-19 July 1998, Roanoke, USA, pp. 319341.

Minitab Reference Manuel (release 15), Minitab Inc. State University Michigan.

Naylor R. L., R. J. Goldburg, J. H. Primavera, N. Kaustky, M. C. M. Beveridge, J. Clay, C. Folke, J. Lubchenco, H. Mooney and M. Troell, 2000. Effect of Aquaculture on World Fish Supplies. Nature, Vol. 405, No. 6790, 2000, pp. 1017-1024. doi:10.1038/35016500. 
Piedrahita, R.H., 2003. Reducing the potential environmental impact of tank aquaculture effluents through intensification and recirculation. Aquaculture. 226(1-4), 35-44.

Piedrahita, R.H., Giovannini, P., 1989. Diel aquaculture models: listings, descriptions and operating instructions. Technical Committee Meeting 1989, PD/A CRSP, Davis, CA, 50 pp.

Piedrahita, R.H., W.H. Zachritz II, K. Fitzsimmons and C. Brockway., 1996. Evaluation and improvements of solids removal systems for aquaculture. Pp. 141-150 in G.S. Libey and M.B. Timmons, editors. Aquacultural Engineering Society Proceedings II: Successes and failures in commercial recirculating aquaculture. Northeast Regional Agricultural Engineering Service, Ithaca, New York.

Quazi RM., 2001. Strategic Water Resources Planning: A case Study of Banglandesh. Water Resour. Manage. 15: 165-186.

Read, P., Fernandes, T., 2003. Management of environmental impacts of marine aquaculture in Europe. Aquaculture 226, 139-163.

Remen M., Imsland A.K., Steffanson S.O., Jonassen T.M., Foss A., 2008. Interactive effects of ammonia and oxygen on growth and physiological status of juvenile Atlantic cod (Gadus morhua) - Aquaculture 274: 292299.

Rosenthal, H., Castell, J. D., Chiba, K., Forster, J. R. M., Hilge, V., Hogendoorn, H.,Mayo, R. D., Muir, J. F., Murray, K. R., Petit, J., Wedemeyer, G. A., Wheaton, F., Wickins, J., 1986. Flow-through and recirculation systems, EIFAC: 100.

Russel Water Gardens, 2011. The HydroBead Vortex. Redmond, WA. [http://www.russellwatergardens.com/Filters/hydrobeadvortex3.php?PH PSESSID=394272e 7ca0fa54533fbe7981df4c0a9].

Sammouth S, d'Orbcastel ER, Gasset E, Lemarié G, Breuil G, Marino G, Coeurdacier JL, Fivelstad S and Blancheton JP., 2009. The effect of density on sea bass (Dicentrarchus labrax) performance in a tank-based recirculating system. Aquac Eng 40, 72-78.

Sandu SI, Boardman GD, Watten BJ and Brazil BL., 2002. Factors influencing the nitrification efficiency of fluidized bed filter with a plastic bead medium. Aquac Eng 26, 41-59. 
Selective Koi Sales, 2011. Econobead filters. Hainford, UK. [http://www.selectivekoisales .co.uk/shop/index.php?cPath=67_17].

Summerfelt, S.T. 2006. Design and management of conventional fluidizedsand biofilters. Aquac Eng. 34, 275-302.

Summerfelt, S.T., 1996. Engineering design of modular and scaleable recirculating systems containing circular tank, microscreen filters, fluidized-sand biofilters, cascade aerators, and low head or u-tube oxygenators. In: Successes and Failures in Commercial Recirculating Aquaculture, Editors Northeast Regional Agricultural Engineering Service (NRAES). NRAES-98, 1, pp. 217-244.

Summerfelt, S.T., Sharrer, M.J., Tsukuda, S.M., Gearheart, M., 2009. Process requirements for achieving full-flow disinfection of recirculating water using ozonation and UV irradiation Aquacult. Eng. 40, 17-27.

Tal, Y., Schreier, H.J., Sowers, K.R., Stubblefield, J.D., Place, A.R., Zohar, Y., 2009. Environmentally sustainable land-based marine aquaculture. Aquaculture 286, 28-35.

Timmons, M.B., Ebeling, J.M., 2007. Recirculating Aquaculture. NRAC Publications, No. 01-007. Cayuga Aqua Ventures, Ithaca, NY, 49.

Verdegem, M. C. J., Bosma, R. H., Verreth, J. A. J., 2006. Reducing water use for animal production through aquaculture. Int. J. Water Resour. Dev. $22,101-113$.

Wedemeyer, G.A., 1996. Physiology of fish in intensive culture systems. Chapman and Hall, New York.

Welch, E.B., Lindell, T., 1992. Ecological Effects of Wastewater. Applied Limnology and Pollutant Effects. Chapman and Hall, London, pp. 76-81.

Wheaton, F. W., Hochheimer, J. N., Kaiser, G. E., Malone, R. F., Krones, M.J., Libey, G. S. Easter, C.C.1994. Nitrification filter design methods. In: Aquaculture Water Reuse Systems: Engineering Design and Management. Development in Aquaculture and Fisheries Science. Vol.27. Timmons MB and Losordo TM, eds. Elsevier, Amsterdam, NL, pp. 127-171.

Wickens, J.F., 1980. Water quality requirements for intensive aquaculture: a review. In: Proceedings of the Symposium on New Developments in the 
Utilization of Heated Effluents and Recirculation Systems on Intensive Aquaculture, 11th session, pp. 28-30.

Zohar, Y., Tal, Y., Schreier, H. J., Steven, C., Stubblefield, J. and Place., A., 2005. Commercially feasible urban recirculated aquaculture: Addressing the marine sector. In, Urban Aquaculture, B. Costa-Pierce, ed. CABI Publishing, Cambridge, MA, pp. 159-171.

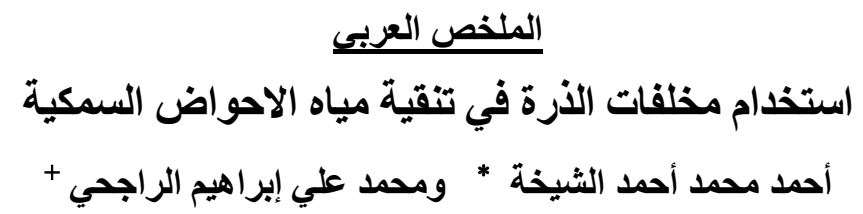

يتم استخدام نظام إعادة تنقية المياه علي نطاق واسع بالزر اعات المائية وذللك لإز الة المخلفات

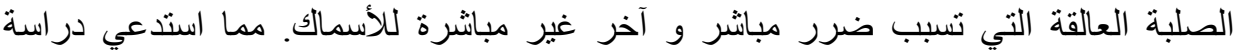

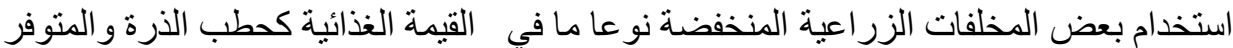
بكثرة في الريف المصري و التي يؤدي تر اكمه بالحقل إلي كوارث الهية ومشاكل بيئية كثيرة كانتشار

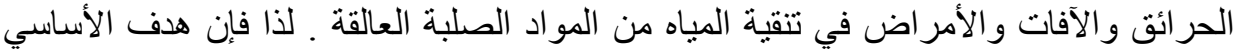

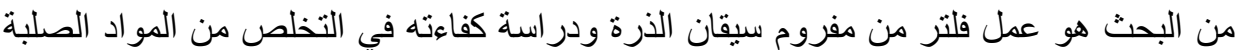

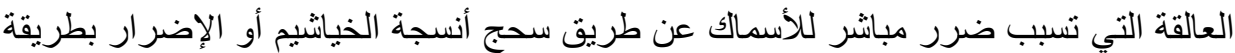
غير مبانشرة عن طريق تعكير الماء. تمت الدراسة علي مجموعة من الأسماك المرباه في لإني

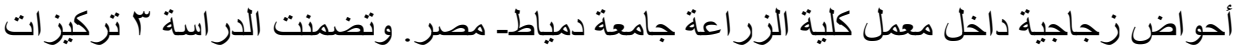

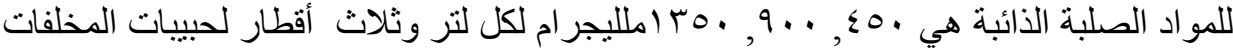

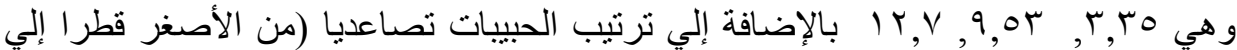

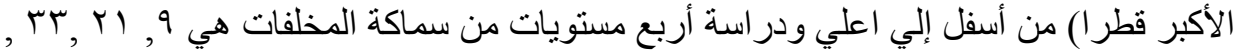

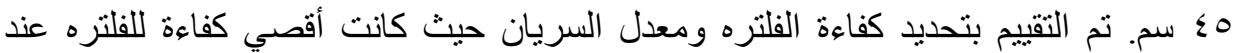

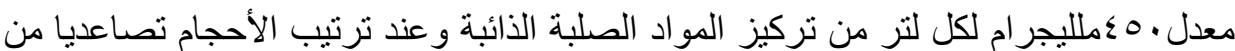

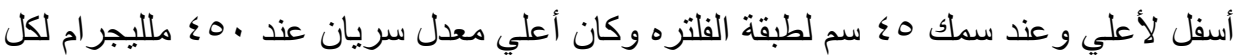

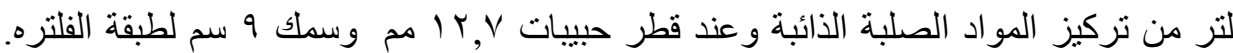

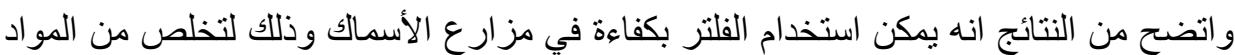

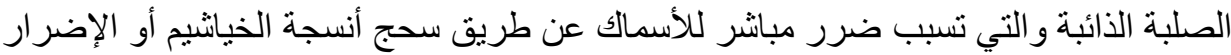
بطريقة غير مباشرة عن طريق تعكير الماءو الذي يؤدي أيضا إلي اختناق الأسماك.

* مدرس الهندة الزراعية ـ كلية الزراعة جامعة دمياط باحث بمعهد بحوث الهندسة الزراعيةـ مركز البحوث الزئة الزراعية 